\title{
Pregnant women with morbid obesity: pregnancy and perinatal outcomes
}

\begin{abstract}
Aim: evaluating obstetric complications and perinatal outcomes in pregnant women with morbid obesity (BMI $\geq 40.0 \mathrm{~kg} / \mathrm{m}^{2}$ ) compared to pregnant women with normal weight (BMI 18.5-24.9 $\mathrm{kg} / \mathrm{m}^{2}$ ).
\end{abstract}

Methods: It is a retrospective case-control study undertaken by the Department of Obstetrics at Hospital Universitario Doctor Peset, Valencia (Spain) between May 2008 and July 2016.

Results: 50 patients were enrolled in each study group. Morbidly obese pregnant patients had a higher rate of nulliparity $(\mathrm{P}=0.03)$, chronic hypertension $(\mathrm{P}=0.008)$, preeclampsia $(\mathrm{P}=0.03)$, gestational diabetes $(\mathrm{P}=0.013)$ and delivery by caesarean section $(\mathrm{P}=0.04)$ compared to control patients with normal weight.

Conclusion: Closer monitoring of morbidly obese pregnant women is recommended to prevent, reduce and properly handle the complications that may arise during pregnancy, both for the mother and the fetus.
Volume 8 Issue 5 - 2018

\author{
Amparo Carrasco Catena,' Nerea Ruiz \\ Sacedón,' Ester Ortiz Murillo,' Reyes \\ Balanzá Chancosa ${ }^{2}$ \\ 'Consultant (UK) in Obstetrics and Gynaecology at Hospital \\ Doctor Peset, Spain \\ ${ }^{2} \mathrm{Head}$ of the Department of Obstetrics and Gynaecology at \\ Hospital Doctor Peset, Spain
}

\begin{abstract}
Correspondence: Ester Ortiz Murillo, Department of Obstetrics and Gynaecology. Hospital Universitario Doctor Peset, Av. Gaspar Aguilar 90. 46017 Valencia, Spain, Tel 961624416, Email esterortizmurillo@gmail.com
\end{abstract}

Received: September 14, 2018 | Published: September 26, 2018

Keywords: obesity, morbid obesity, pregnancy complications, maternal outcomes, perinatal outcomes

\section{Introduction}

There is an increase in obesity in developed countries, multifactorial in origin, which combines the lack of physical exercise, changes in diet composition and increased caloric intake. Although overweight is an increasingly important global health problem, the lack of motivation to face it more decisively in daily clinical practice is worrying. The World Health Organization defines regular weight, overweight, obesity and morbid obesity as body mass index (BMI) of 18.5 to 24.9 ; 25 to $29.9 ; 30$ to 39.9 and 40 or higher, respectively. Spain is not an exception to this trend, but rather the opposite. Obesity in our country is reaching more worrying figures and comparative studies with other countries around place us at the forefront, with overall prevalence figures, both in children and adults, of around $25 \% .{ }^{1}$ According to the latest National Health Survey of Spain published in 2012, the chief results highlight the continuous rise in obesity, affecting $17 \%$ of the adult population (INE 2013).

The prevalence of obesity in women of reproductive age and pregnant women varies widely depending on the definition, the year and the characteristics of the study population, but it has increased in line with an increased prevalence of obesity in the general population. This alarming increase has made that more than a fifth of the European women who become pregnant in developed countries enter the clinical category of obesity. ${ }^{2,3}$ Obesity in women can negatively affect the course of pregnancy, with complications include: gestational diabetes, ${ }^{4}$ gestational hypertension or preeclampsia, ${ }^{5}$ thromboembolism, ${ }^{6}$ back pain, sciatic pain, increased fatigue, ${ }^{7}$ slower labour progression, ${ }^{8}$ higher rate of instrumental or caesarean deliveries, surgical wound infection, postpartum hemorrhage ${ }^{4}$ and maternal death. ${ }^{9}$ Fetal risks associated with obese pregnant women include: spontaneous abortions, congenital anomalies ${ }^{10}$ macrosomia, ${ }^{11}$ shoulder dystocia, stillbirth $^{12}$ and neonatal death. ${ }^{13}$

A 2010 publication of the Royal College of Obstetricians and
Gynaecologists (RCOG) gathers the rate of complications associated with obesity during pregnancy and includes: hypertensive disorders (OR 3.3, 95\% CI 2.7-3.9), venous thromboembolism (OR 9.7, 95\% CI 3.1-30.8), gestational diabetes (OR 2.4, 95\% CI 2.2-2.7), elective caesarean section (OR 2.1, 95\% CI 1.9-2.3), emergency caesarean section (OR 2.0, 95\% CI 1.2-3.5), postpartum hemorrhage (OR 2.3, $95 \%$ CI 2.1-2.6), surgical wound infection (OR 2.2, 95\% CI 1.0-2.6), congenital malformations (OR 1.6, 95\% CI 1.0-2.5), prematurity (OR $1.2,95 \%$ CI 1.1-1.4), macrosomia (OR 2.4, 95\% CI 2.2-2.5), shoulder dystocia (OR 2.9, 95\% CI 1.4-5.8), neonatal admission (OR 1.5, 95\% CI 1.1-2.3), stillbirth (OR 2.1, 95\% CI 1.5-2.7) and neonatal death (OR 2.6, 95\% CI 1.2-5.8) (RCOG 2010).

The main aim of our study is to evaluate obstetric complications and perinatal outcomes in patients with morbid obesity (BMI $\geq 40.0$ $\mathrm{kg} / \mathrm{m}^{2}$ ) controlled in the Obstetric Unit of Hospital Universitario Dr. Peset in Valencia, Spain. Its secondary objective is to compare the results obtained in morbidly obese patients with a control group of pregnant women with normal weight (BMI 18.5-24.9 $\mathrm{kg} / \mathrm{m}^{2}$ ) controlled in the same Hospital Unit.

\section{Materials and methods}

This is an observational and retrospective case-control study in which obstetrical complications and perinatal outcomes in patients with morbid obesity $\left(\mathrm{BMI} \geq 40.0 \mathrm{~kg} / \mathrm{m}^{2}\right)$ were evaluated and compared with those in patients with normal weight (BMI 18.5 to $24.9 \mathrm{~kg} / \mathrm{m}^{2}$ ) in the time period between May 2008 and July 2016.

In the case group, patients with singleton pregnancies, controlled in our High Risk Obstetric Unit and who met the criteria for morbid obesity - defined as BMI $\geq 40 \mathrm{~kg} / \mathrm{m}^{2}$ according to the World Health Organization (WHO) - were included. The control group was made of patients with singleton pregnancies and normal weight (BMI 18.5$24.9 \mathrm{~kg} / \mathrm{m}^{2}$ ) controlled in the same Hospital Unit during the same 
period.

The maternal characteristics included and compared between the two groups were: age, parity, BMI, pregestational diabetes and chronic hypertension. The analyzed maternal outcomes included preeclampsia, gestational diabetes, and spontaneous onset of labour versus induced labour, mode of delivery, postpartum hemorrhage and venous thromboembolism. As neonatal outcomes, gestational age at birth, prematurity (defined as gestational age less than 37 weeks), weight at birth, Apgar score at one minute and five minutes after birth and umbilical cord blood $\mathrm{pH}$ were included. The analysis of the data and the results were obtained by using the statistical software SPSS version 20 and Microsoft Excel 2007. For both groups descriptive statistics were used. The variables are expressed in percentages and means \pm standard error. The statistical significance tests used were the Chi-square and Fisher's exact test for dichotomous qualitative variables and the Student $t$ for continuous variables. For quantitative variables, multiple regression models were used. In all cases, statistically significant differences were considered when $p<0.05$. The study was approved by the Ethics Committee for Ethics in Clinical Research of the hospital. Informed consent was obtained from all the participants and the confidentiality of all of them was maintained.

\section{Results}

A total of 50 patients were included in both study groups.

The demographic characteristics of both groups are shown in Table 1. Within the group of morbidly obese patients, the mean age was 30.95 years (22-45) and the mean BMI $43.36 \mathrm{~kg} / \mathrm{m}^{2}(40-58)$. In the group of patients with normal weight, the average age was 29.76 years (22-41) and the average BMI $22.27 \mathrm{~kg} / \mathrm{m}^{2}(20-24.9)$.

Table I Demographic characteristics of the patients ${ }^{\mathrm{a}}$

\begin{tabular}{|c|c|c|c|}
\hline Characteristics & $\begin{array}{l}\text { Pregnant } \\
\text { women } \\
\text { with normal } \\
\text { weight } \\
(n=50)^{b}\end{array}$ & $\begin{array}{l}\text { Pregnant } \\
\text { women with } \\
\text { morbid obesity } \\
(n=50)^{c}\end{array}$ & P value \\
\hline Age (years) & 29.76 & 30.95 & - \\
\hline BMI $\left(\mathrm{kg} / \mathrm{m}^{2}\right)$ & 22.27 & 43.36 & - \\
\hline \multirow[t]{3}{*}{ Parity } & $\begin{array}{l}\text { Nulliparous } 23 \\
(46)\end{array}$ & $\begin{array}{l}\text { Nulliparous } 20 \\
(40)\end{array}$ & 0.03 \\
\hline & $\begin{array}{l}\text { Prev. caesarean } \\
\text { section } 16(32)\end{array}$ & $\begin{array}{l}\text { Prev. caesarean } \\
\text { section } 19(38)\end{array}$ & NS \\
\hline & $\begin{array}{l}\text { Prev. vaginal } \\
\text { delivery I0 (20) }\end{array}$ & $\begin{array}{l}\text { Prev. vaginal } \\
\text { delivery II (22) }\end{array}$ & NS \\
\hline $\begin{array}{l}\text { Pregestational } \\
\text { diabetes }\end{array}$ & I (2) & $5(10)$ & NS \\
\hline $\begin{array}{l}\text { Chronic } \\
\text { hypertension }\end{array}$ & I (2) & $10(20)$ & 0.008 \\
\hline
\end{tabular}

Abbreviations: BMI, Body Mass Index; NS, Not Significant

a Mean values \pm standard deviations or percentage (\%)

bBMI $20.0-24.9 \mathrm{~kg} / \mathrm{m}^{2}$

${ }^{\mathrm{c}} \mathrm{BMI} \geq 40 \mathrm{~kg} / \mathrm{m}^{2}$

The morbidly obese patients had a higher rate of nulliparity $(\mathrm{P}=0.03)$ and chronic hypertension $(\mathrm{P}=0.008)$ than patients with normal weight. Neither statistically significant differences in the previous mode of delivery (caesarean section or vaginal) nor a history of pregestational diabetes were found.

Maternal outcomes were obtained by univariate analysis and are shown in Table 2. In the group of morbidly obese patients, higher rates of preeclampsia $(\mathrm{P}=0.03)$, gestational diabetes $(\mathrm{P}=0.013)$ and delivery by caesarean section $(\mathrm{P}=0.04)$ were recorded compared to control patients with normal weight. There were no differences in the onset of labour and in the occurrence of postpartum venous thromboembolism between the two study groups. However, there were more cases of postpartum hemorrhage in obese patients than in the group of patients with normal weight ( $14 \%$ vs $4 \%$ ), but this difference did not reach statistical significance. Perinatal outcomes of the study are shown in Table 3. In our study, no statistically significant differences in terms of perinatal outcomes were found compared to those obtained in the group of patients with normal weight.

Table 2 Maternal outcomes ${ }^{\mathrm{a}}$

\begin{tabular}{|c|c|c|c|}
\hline Results & $\begin{array}{l}\text { Pregnant } \\
\text { women with } \\
\text { normal weight } \\
(n=50)^{b}\end{array}$ & $\begin{array}{l}\text { Pregnant } \\
\text { women with } \\
\text { morbid obesity } \\
(n=50)^{c}\end{array}$ & $P$ value \\
\hline Preeclampsia & $2(4)$ & $10(20)$ & 0.03 \\
\hline $\begin{array}{l}\text { Gestational } \\
\text { diabetes }\end{array}$ & $3(6)$ & $12(24)$ & 0.013 \\
\hline \multirow[t]{2}{*}{ Onset of labour } & $\begin{array}{l}\text { Spontaneous } 27 \\
(54)\end{array}$ & $\begin{array}{l}\text { Spontaneous I4 } \\
\text { (28) }\end{array}$ & NS \\
\hline & Induced 23 (46) & Induced 36 (72) & NS \\
\hline \multirow[t]{2}{*}{ Delivery } & Vaginal 36 (72) & Vaginal $28(56)$ & NS \\
\hline & $\begin{array}{l}\text { Caesarean } \\
\text { section } 14 \text { (28) }\end{array}$ & $\begin{array}{l}\text { Caesarean } \\
\text { section } 22(44)\end{array}$ & 0.04 \\
\hline $\begin{array}{l}\text { Postpartum } \\
\text { hemorrhage }\end{array}$ & $2(4)$ & $7(14)$ & NS \\
\hline $\begin{array}{l}\text { Venous } \\
\text { tromboembolism }\end{array}$ & 0 & 0 & NS \\
\hline
\end{tabular}

Abbreviations: BMI, Body Mass Index; NS, Not Significant. ${ }^{a}$

Mean values \pm standard deviations or percentage (\%)

'BMI $20.0-24.9 \mathrm{~kg} / \mathrm{m}^{2}$

'BMI $\geq 40 \mathrm{~kg} / \mathrm{m}^{2}$

Table 3 Perinatal results ${ }^{\mathrm{a}}$

\begin{tabular}{|c|c|c|c|}
\hline Results & $\begin{array}{l}\text { Pregnant } \\
\text { women with } \\
\text { normal weight } \\
(n=50)^{b}\end{array}$ & $\begin{array}{l}\text { Pregnant } \\
\text { women } \\
\text { with normal } \\
\text { obesity } \\
(n=50)^{c}\end{array}$ & $P$ value \\
\hline $\begin{array}{l}\text { Gestational age >37 } \\
\text { weeks }\end{array}$ & $49(98)$ & $48(96)$ & NS \\
\hline $\begin{array}{l}\text { Gestational age }<37 \\
\text { weeks }\end{array}$ & I (2) & $2(4)$ & NS \\
\hline $\begin{array}{l}\text { Weight after birth } \\
\text { (g) }\end{array}$ & $3668 \pm 158$ & $3880 \pm 191$ & NS \\
\hline $\begin{array}{l}\text { Weight after birth > } \\
4000 \mathrm{~g}\end{array}$ & $4(8)$ & $8(16)$ & NS \\
\hline $\begin{array}{l}\text { Weight after birth < } \\
2500 \mathrm{~g}\end{array}$ & $2(4)$ & $4(8)$ & NS \\
\hline Apgar < 7 (I minut) & I (2) & $7(14)$ & NS \\
\hline Apgar < 7 (5 minuts) & I (2) & 0 & NS \\
\hline $\begin{array}{l}\text { Umbilical cord blood } \\
\mathrm{pH}<7,20\end{array}$ & $5(10)$ & $9(18)$ & NS \\
\hline
\end{tabular}

Abbreviations: NS, Not Significant

aean values \pm standard deviations or percentage (\%)

'BMI $20.0-24.9 \mathrm{~kg} / \mathrm{m}^{2}$

CBMI $\geq 40 \mathrm{~kg} / \mathrm{m}^{2}$ 


\section{Discussion}

Overweight and obesity among pregnant women have recently become a worldwide problem.

Obesity during pregnancy is associated with many maternal and perinatal risks. The appearance of these risks is proportional to the degree of obesity presented by the patient. ${ }^{14-16}$ Managing these problems and potentially reduce their risks is currently a challenge for specialists in Obstetrics. ${ }^{17}$ In our review, morbidly obese patients (BMI $\left.\geq 40.0 \mathrm{~kg} / \mathrm{m}^{2}\right)$ had higher nulliparity $(40 \%)$ and chronic hypertension $(20 \%)$ rates than control patients with normal weight. However no significant data regarding pregestational diabetes were found. These data are consistent with the study published by Crane et al (Crane et al. 2013), where pregnant women with extreme obesity (BMI $\geq 50 \mathrm{~kg} /$ $\mathrm{m}^{2}$ ) presented higher nulliparity $(59.2 \%)$, chronic hypertension $(7 \%)$ and pregestational diabetes $(5.6 \%)$ rates than the control patients with normal weight.

According to our figures, from the total of our obese pregnant patients, $10(20 \%)$ had preeclampsia, $12(24 \%)$ gestational diabetes and $22(44 \%)$ delivered by caesarean section. $4(8 \%)$ out of the obese pregnant women who developed preeclampsia during pregnancy, suffered already from chronic hypertension at the beginning of the study. These data are similar to those obtained in other studies. ${ }^{18,19}$ According to the literature reviewed, pregnant women with obesity $\left(\mathrm{BMI} \geq 30.0 \mathrm{~kg} / \mathrm{m}^{2}\right.$ have a higher prevalence of gestational diabetes, ${ }^{20,21}$ higher rates of hypertensive disorders of pregnancy ${ }^{22-24}$ and a higher rate of induction and failure of labour induction ${ }^{25,26}$ than the general obstetric population.

In our study, a total of 7 patients (14\%) had postpartum hemorrhage, all managed by conservative measures. With regard to venous thromboembolism, no cases were found in any of our both study groups. This result can be explained because all the morbidly obese pregnant patients in our Obstetrics Unit are treated with low molecular weight heparins in prophylactic doses administered daily during pregnancy. According to the latest Uptodate 2016 on obesity and pregnancy, there is a clear association between maternal obesity and the risk of postpartum hemorrhage ${ }^{4}$ and venous thromboembolism. ${ }^{27}$

In our review, the average weight of the babies of morbidly obese mothers was 3880 g. $4 \%$ of fetuses were premature compared to $8.5 \%$ in other studies (). The percentage of macrosomes was $16 \%$ in contrast to $38 \%$ in Crane et al. ${ }^{18}$ or $12.3 \%$ in Wahhabi et al. ${ }^{28}$ Total newborns weighing $<2500$ g. was $4(8 \%)$, a figure that contrasts with other studies where the percentage is around 4\% (Crane et al. 2013; Wahabi et al. 2014). This data is justified by the percentage of chronic hypertensive patients among the obese patients included in the study. According to similar studies published, pregnant women with morbid obesity present higher risk of congenital malformations, ${ }^{28}$ prematurity, macrosomic fetuses, shoulder dystocia ${ }^{30}$ as well as neonatal admissions, stilldeath and neonatal death. ${ }^{29}$ We are aware of the limitations of our study. On the one hand, because of the retrospective nature of our research; on the other hand, because of the small sample size of the study group $(\mathrm{N}=50)$. This could explain the lack of statistical significance in most of the variables studied.

\section{Conclusion}

Pregnant women with morbid obesity $\left(\mathrm{BMI} \geq 40.0 \mathrm{~kg} / \mathrm{m}^{2}\right)$ present a higher risk of maternal and perinatal complications. Therefore, further development and the elaboration of programs from the preconception period are recommended. This should be done in specialized units that value individual needs and the risk factors of each patient in order to prevent, reduce and properly handle the complications that may arise for both mother and fetus.

\section{Acknowledgement}

The authors extend their appreciation to JJT for the statistical analysis.

\section{Funding}

This study was undertaken without specific financial support.

\section{Conflict of interest}

The authors declare no conflict of interest. The authors are the only responsible for the content and the writing of the paper.

\section{References}

1. Finucane MM, Stevens GA, Cowan MJ, et al. National, regional, and global trends in body-mass index since 1980: systematic analysis of health examination surveys and epidemiological studies with 960 country-years and 9.1 million participants. Lancet. 2011;377(9765):557-567.

2. WHO. WHO Global Database on Body Mass Index. 2014

3. Basterra-Gortari FJ, Beunza JJ, Bes-Rastrollo M, et al. Increasing Trend in the Prevalence of Morbid Obesity in Spain: From 1.8 to 6.1 per Thousand in 14 Years. Revista Española Cardiología. 2011;64(5):424 426.

4. Sebire NJ, Jolly M, Harris JP, et al. Maternal obesity and pregnancy outcome: a study of 287,213 pregnancies in London. Int J Obes Relat Metab Disord. 2001;25(8):1175-1182.

5. Bhattacharya S, Campbell DM, Liston WA, et al. Effect of Body Mass Index on pregnancy outcomes in nulliparous women delivering singleton babies. BMC Public Health. 2007;7(1):168.

6. Larsena TB, Sørensenb HT, Gislumb M, et al. Maternal smoking, obesity, and risk of venous thromboembolism during pregnancy and the puerperium: A population-based nested case-control study. Thrombosis Research. 2007;120(4): 505-509.

7. Agha M, Agha RA, Sandell J. Interventions to reduce and prevent obesity in pre-conceptual and pregnant women: a systematic review and meta-analysis. Plos One. 2014;9(5):e95132.

8. Vahratian A, Zhang J, Troendle JF, et al. Maternal prepregnancy overweight and obesity and the pattern of labor progression in term nulliparous women. Obstet Gynecol. 2004;104(5 Pt 1): 943-951.

9. Drife J. Confidential Enquiry into Maternal and Child Health, Why Mothers Die 2000-2002. Journal of Royal College of Physicians Edinburgh. 2005;35:332-336.

10. Stothard SA, Tennant PW, Bell R, et al. Maternal overweight and obesity and the risk of congenital anomalies: a systematic review and meta-analysis. JAMA. 2009;301(6):636-650.

11. Bianco AT, Smilen SW, Davis Y, et al. Pregnancy outcome and weight gain recommendations for the morbidly obese woman. Obstet Gynecol. 1998;91(1):97-102.

12. Chu SY, Kim SY, Lau JJ, et al. Maternal obesity and risk of stillbirth: a metaanalysis. Am J Obstet Gynecol. 2007;197(3):223-228.

13. Kristensen J, Vestergaard M, Wisborg K, et al. Prepregnancy weight and the risk of stillbirth and neonatal death. BJOG. 2005;112(4):403408 . 
14. Torloni MR, Betrán AP, Horta BL, et al. Prepregnancy BMI and the risk of gestational diabetes: a systematic review of the literature with meta-analysis. Obesity Reviews. 2009;10(2):194-203.

15. Scott-Pillai R, Spence D, Cardwell CR, et al. The impact of body mass index on maternal and neonatal outcomes: a retrospective study in a UK obstetric population, 2004-2011. BJOG. 2013;120(8):932-939.

16. Blomberg M. Maternal obesity, mode of delivery, and neonatal outcome. Obstet Gynecol. 2013;122(1):50-55.

17. Gunatilake RP, Perlow JH. Obesity and pregnancy: clinical management of the obese gravida. American Journal of Obstetrics and Gynecology. 2011;204(2):106-119.

18. Crane JMG, Murphy P, Burrage L, et al. Maternal and perinatal outcomes of extreme obesity in pregnancy. J Obstet Gynaecol Can. 2013;35(7):606-611.

19. Weiss JL. Malone FD, Emig D, et al. Obesity, obstetric complications and cesarean delivery rate: A population-based screening study. $\mathrm{Am} \mathrm{J}$ Obstet Gynecol. 2004;190:1091-1097.

20. Ehrenberg HM, Dierker L, Milluzzi C, et al. Prevalence of maternal obesity in an urban center. American Journal of Obstetrics and Gynecology. 2002;187(5):1189-1193.

21. Gross T, Sokol RJ, King KC. Obesity in pregnancy: risks and outcome. Obstetrics and Gynecology. 1980;56:446.

22. Robinson HE, O'Connell CM, Joseph KS, et al. Maternal outcomes in pregnancies complicated by obesity. Obstet Gynecol.
2005;106(6):1357-1364.

23. O'Brien TE, Ray JG, Chan WS. Maternal body mass index and the risk of preeclampsia: a systematic overview. Epidemiology. 2003;14(3):368-374.

24. Gaillard R, Steegers EA, Hofman A, et al. Associations of maternal obesity with blood pressure and the risks of gestational hypertensive disorders. The Generation R Study. J Hyperten. 2011;29(5):937-944.

25. Denison FC, Price J, Graham C, et al. Maternal obesity, length of gestation, risk of postdates pregnancy and spontaneous onset of labour at term. BJOG. 2008;115(6):720-725.

26. Wolfe KB, Rossi RA, Warshak CR. The effect of maternal obesity on the rate of failed induction of labor. American Journal of Obstetrics and Gynecology. 2011;205:128.

27. Nuthalapaty FS, Rouse DJ. The impact of obesity on female fertility and pregnancy. 2016.

28. Wahabi HA, Fayed AA, Alzeidan RA, et al. The independent effects of maternal obesity and gestational diabetes on the pregnancy outcomes. BMC Endocrine Disordes. 2014;14:47.

29. Aune D, Saugstad OD, Henriksen T, et al. Maternal body mass index and the risk of fetal death, stillbirth, and infant death: a systematic review and meta-analysis. JAMA. 2014;311(15):1536-1546.

30. RCOG. Management of Women with Obesity in Pregnancy Guideline. London: Royal College of Obstetricians and Gynaecologistis; 2010. 